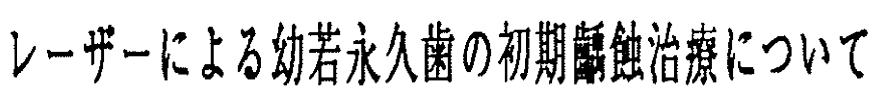

\author{
山田恵子
}

東北大学菌学部小児柬科学諘座

\section{Treatrent with laser and fluoride application on incipient caries of young perianent teeth}

\author{
Keiko Yamada \\ Dept. of Pediatric Dentistry, Tohoku University School of Dentistry
}

Abstract

Nd:YAG laser and acidulated phosphate fluoride (APF) weres applied on incipient caries of young permanent teeth. They were followed up for at least two years to investigate the effect of a combinate application of laser and fluoride on inhibition of demineralization of incipient caries. The results were as follows. (1) The roughnesses of the enamel surfaces treated with laser and APF were altered for smoother in $80 \%$ of the subjects and white lesions were changed to clear surfaces in $60 \%$ of the subjects. (2) Decalcification of pits and fissures having stains was inhibited by the combinate application in $54 \%$ of the subjects, however, the rest of them were shown caries induced.

はじめに

萌出間も無い幼若永久菌のエナメル質は 末成熟であることより早期に䠛蝕に羅患し やすい。一方、この様な幼若永久歯を有す
る蒾列は咬合がまだ安定していないことが 多く、金属を用いた永久修復を適応するこ とは危険である。また、最近の礼科治療の 考え方としてできるだけ歯質の削除它行わ ずに病紧の再石灰化を促す方法が推奖され 
る傾向にある。

以上の様な理由により幼若永久歯の初期 䶖蝕の脱灰進行抑制に効果的な手段が望ま れている。

筆者はNd:YAGレーザーがエナメル質の耐 酸性を堌強する効果を利用して幼若永久蒾 の初期䠛蝕の治療にレーザーとフッ菜塗布 併用法を応用し、その追跡調查を行ってい る。今回はNd:YAG laser, DCL8の初期齔蝕 治療への応用に関する治験研究症例の中で 2 年間以上追跡可能であった症例の観察所 見結果を報告するととすに、すでにこれま で報告した筆者の他の臨床結果との比較を 行い、考察したい。

\section{治输研究加ら}

1 幼若永久歯平滑面の初期䠛蝕治療 <対象及び方法 >

平滑面に初期鬴蝕によると思われる白濁 と粗雜感を呈している幼若永久歯である。 方法は、(1)咬合面をブラシコーンにて注水 下で機械的清掃後水洗、乾燥、(2)白溞平滑 面に光吸収剤（黒色）を深布し、乾燥、

(3)パルス波Nd:YAGレーザー（DCL8 SLTJapa n社) を照射 $\left(40 \sim 50 \mathrm{~J} / \mathrm{cm}^{2}\right)$ 、(4)吸収郕を ブラシコーンで除去、(5)APF塗布（4 分間） とした。

<結果>

2 年間以上の追跡が可能であった 30 歯 について 1 年〜 1 年 6 ヶ月（第 1 期）、 2 年〜 2 年 6 ヶ月（第 2 期）の時点での所見 をまとめると（Table1）、白濁の一部あ
るいは殆どの消失を認めたのは第 1 期では 17 歯（56.7\%）、第 2 期で 19 歯 （6 $3.3 \% ） 、$ 白濁の変化なし第 1 期で が 12 歯（40．0\%）、第 2 期で 9 歯 （３０．０％）、また、表面の滑沢化を認 めたものは第 1 期で 26 菌（86．7\%）、 第 2 期で 24 崡（80．0\%）、依然とし て同程度の粗雜感が残ったものは第 1 期で 3 歯（10．0\%）、第 2 期で 4 歯であっ た。さらに䶞蝕の進行による実質欠損を認 めたのが第 1 期で 1 蓬、第 2 期で 2 崡（6. $7 \%$ ）であった。

Table.1. Finding of Pit and Fissure Treated by Laser and APF

\begin{tabular}{ccc}
\hline Finding & $\begin{array}{c}\text { Before } \\
\text { treatment }\end{array}$ & $2 \mathrm{y} \sim 2 \mathrm{y6m}$ \\
\hline $\mathrm{CO}$ & 11 & $6(54.5)$ \\
$\mathrm{C}_{1}$ & 0 & $3(27.3)$ \\
$\mathrm{C}_{2}$ & 0 & $2(18.2)$ \\
\hline Total & 11 & $11(100)$ \\
\hline
\end{tabular}

$(x)=(\mathrm{No} / \mathrm{Tot}$ ) $) \times 100$

2 幼若永久崡咬合面の初期唃蝕治療

<対象及び方法>

治験対象は全咬合面が萌出している幼若 永久菌四歯で裂溝が着色しているが、探針 による診查でスティッキー感のない初期䶖 蝕菌（ＣＯ） 11 歯とした。方法は前述の 平滑面と同様である。

$<$ 結果 $>$

2 年間以上の経過観察が可能であったの は11歯（大田歯 9、小罒歯 2) であった が、 2 年〜 2 年 6 ヶの観察所見をまとめ ると (Table2)、6 歯（54．5\%）は依 然としてCO（着色あり、スティッキー感 
なし)であったが、C、に移行した歯は 3 歯（27.3\%）で1歯にはフィッシャ一 シーラント、2 歯にレジン充填を施した。 また、 $C_{2}$ に移行した歯は 2 例（１８．２２ \%）であり、いずれむレジン充填を行ったc

Table.2. Finding of Enamel Surface Treated by Laser and APF

\begin{tabular}{|c|c|c|c|}
\hline Finding & $\begin{array}{c}\text { Before } \\
\text { treatment }\end{array}$ & $\begin{array}{l}\text { Period } \\
(1 \mathrm{y} \sim 1 \mathrm{y} 6 \mathrm{~m})\end{array}$ & $\begin{array}{l}\text { Period } \| \\
\left(2 \mathrm{y} \sim 2 \mathrm{y}^{6} \mathrm{~m}\right)\end{array}$ \\
\hline White Lesion & so & $12(40.0)$ & $9(30.0)$ \\
\hline $\begin{array}{l}\text { Partly or } \\
\text { Almostly clear }\end{array}$ & 0 & $17(56.7)$ & $19(63.3)$ \\
\hline Rough & 30 & $3(10.0)$ & $4(13.3)$ \\
\hline $\begin{array}{l}\text { Partly or } \\
\text { Almostly smooth }\end{array}$ & 0 & $26(86.7)$ & $24(80.0)$ \\
\hline Caries & & $1(3.3)$ & $2(6.7)$ \\
\hline
\end{tabular}

(*) $=$ (No/Total) $\times 100$

他の研究結果との比较

（1）健全な幼若永久歯咬合面のレーザー

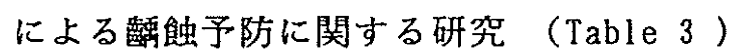

萌出後間も無い健全な永久菌咬合面裂溝 にNd:YAGレーザー(超音波Qスイッチ)を 照射 $\left(50 \sim 60 \mathrm{~J} / \mathrm{cm}^{2}\right)$ してその後追跡観察し た 39 歯のうち、3 歯は $\mathrm{C}_{2}$ と判断され、 フィッシャーシーラントが施された。また、 3 歯は $\mathrm{C}_{2}$ と診断され、アマルガム充填が なされたが、他の 33 菌（84．6\%）は 健全を維持していた。しかす 5 年以上の観 察期間で依然として健全であったすのが 2 3 歯（85．2\%）と多く、超音波Qスイ ッチNd:YAGレーザーが健全裂满部の薸蝕予 防に有効であると思われた。

前述の治験研究は、幼若永久歯の着色を 呈している初期䶡蝕裂溝に対するレーザー の齿蝕進行抑制、再石灰化促進効果を判定 する目的で行ったが、全く健全裂清に回復
したと判定されたものはなく、初期䶚蝕が 進行したすのと、進行が抑制されていたす のが約半数ずっという結果を得た。

Table.3. Clinical Study - Laser application on intact young permanent teeth

\begin{tabular}{|c|c|c|c|}
\hline No. patient (age) & tooth applied & $\begin{array}{l}\text { follow up } \\
\text { period }(y \mathrm{~m})\end{array}$ & dlagnosk at last recall \\
\hline 1. N.K. $(1147 \mathrm{~m})$ & $\frac{5415}{5415}$ & $2 y 7 m$ & intact \\
\hline 2. T.E. $(8 y 5 \mathrm{~m})$ & $\frac{5180}{618}$ & $8 y 3 m$ & $\sqrt{6}: C_{1 \rightarrow F S}$, 司: intact \\
\hline (9yom) & 4.14 & $7 y 0 m$ & intact \\
\hline 3. T.E. $(B y / m)$ & slo & 5yom & intact \\
\hline 4. H.F. $(13,0 \mathrm{~m})$ & $\frac{7654 \mid 6507}{7654 \mid 450}$ & 6y9m & $\frac{77}{77}: C_{2} \rightarrow A F, \frac{65 g / 158}{765 / 456}:$ Intact \\
\hline 5. E.F. (7ym) & $\frac{5}{6} \mid \frac{6}{6}$ & gyom & Intact \\
\hline 6. Kr. (13yom) & $\frac{7417}{7}$ & $2 \mathrm{yom}$ & $\mid \frac{7}{7}: c_{7} \rightarrow$ Fs,$\frac{7}{7} \mid:$ Intact \\
\hline 7. H.Y. $(9 \mathrm{~g} / \mathrm{mm})$ & 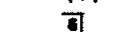 & $2 \mathrm{yom}$ & $c_{1}$ \\
\hline 8. N.K. (10y $11 \mathrm{~m})$ & $\frac{5445}{54155}$ & $1 y 3 m$ & intact \\
\hline
\end{tabular}

この 2 つの研究結果から、（1）健全裂

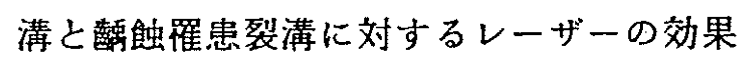
の違い、（2）同じNd:YAGレーザーでも超 音波 $\mathrm{Q}$ スイッとパルス波の発振方式の違 いによる効果の差について考察する。

（1）健全裂清と䀞蝕䍜患裂溝に対する効 果の堂いについて

Nd:YAGレーザーは深達性があるといわれ ているが、照射部に光吸収剂を塗布するこ とによりレーザー光の大部分はその吸収郕 に吸収されることになり、裂溝の深部には 到達していないと推察される。また、裂溝 の初期瀜蝕の診查は視診と探針による触診 とで行ったが、その診查法については未だ に議論のあるところでありさらに客観的な 診查が望まれる。その一つの方法としてカ リエスメーターも使用したが値の安定性に 欠けるところがあり今回は評価に入れなか った。即ち、裂溝の深部に嚙蝕が進行して いた場合にはレーザーの影響が及ばず、齗 蝕の進行は抑制できなかった可能性が示唆 される。 
（2）Nd:YAGレーザーの発振方式の違いに よる効果の差について

森岡らは超音波Qスイッチはエナメル質 にクラックを多く形成し、耐酸性へす悪影 響を与えているとしているが、演者の基礎 的研究に上机ば、超音波Qスイッチも充分 な耐酸性の付与効果が期待できる。また、 健全裂满部の䠓蝕予防を目的とした臨床応 用であ超音波 $\mathrm{Q}$ スイッチレーザーの効果が 立証された。しかし、エナメル質表面の形 態に及ぼす経時的影響についていずれの発 振方式が適当かについては今のところ結論 できない。

（2）幼若永久歯平滑面の初期蹲蝕治療に レーザーを応用した臨床的研究（予備的研 究)

前述した治験研究の予備的研究として、 粗雜感を伴う白斑を呈している幼若永久歯 の平滑面に全く同じ方法でNd:YAGレーザー （Pulsed DCL8)を照射して 2 年間の経過 観察を行ったところ（Table 4)、1 年 7 ヶ 月〜 2 年後の所見は白濁の一部あるいは殆 ど消失したものが約 $50 \%$ 、粗雜感の消失 は $84 \%$ と今回の治験結果と大差無い值を 示していた。また、䠛蝕の進行を認めたも

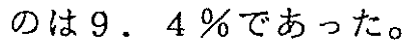

前述の平滑面に対する治験研究結果とこの 結果を比べると、いずれのデー夕すほぼ同 様の值を示したことより、Nd:YAGレーザー は幼若永久歯平滑面の初期䇶蝕治療手段と して有効であると言える。
Table.4. Finding of Enamel Surface Treated by Laser and APF

\begin{tabular}{ccccc}
\hline & $\begin{array}{c}\text { Before } \\
\text { treatment }\end{array}$ & $1 \sim 6 \mathrm{~m}$ & $7 \mathrm{~m} \sim 1 \mathrm{y}$ & $1 \mathrm{y} 7 \mathrm{~m} \sim 2 \mathrm{y}$ \\
\hline White Lesion & & $24(75.0)$ & $19(59.4)$ & $16(50.0)$ \\
Partlyclear & 32 & $8(25.0)$ & $11(34.4)$ & $8(25.0)$ \\
Clear & & $0(0)$ & $1(3.1)$ & $5(15.6)$ \\
\hline Rough & & $7(21.9)$ & $5(15.6)$ & $2(6.3)$ \\
PartlySmooth & 32 & $5(15.6)$ & $2(6.3)$ & $0(0)$ \\
Smooth & & $20(62.5)$ & $24(75.0)$ & $27(84.4)$ \\
\hline Caxios & 0 & $0(0)$ & $1(3.1)$ & $3(9.4)$ \\
\hline Total & 32 & $92(100)$ & $32(100)$ & $32(100)$ \\
\hline
\end{tabular}

$(\%)=($ No/rotal $) \times 100$

しかし、これからの課題として(1)適应症 の選択について客観的評価基準を設定する こと(2)エナメル質の表面の微細構造の経時 的変化について把握しておくことなどが残 されており、現在研究中である。

\section{文献}

1)田籠祥子、森岡俊夫：エナメル質耐酸性 付与に及ぼすYAGレーザー照射と弗化物瀦

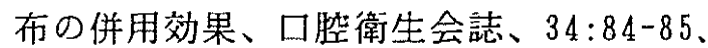
1984

2)山田恵子：小児柬科領域におけるレーザ 一による齨蝕予防に関する研究、小児歯誌、 $23: 575-591,1985$

3)山田恵子、櫻井聡、神山紀久男 : 人工的 初期脱灰エナメル質へのレーザー照射と弗

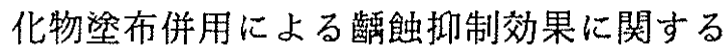
実験的研究、小児歯誌、26:732-741、1988 4) K. YAMADA:Caries prevention by laser irradiation to dental enamel, Proceedings of 5 th Congress of the International Society for Lasers in Dentistry, $131-137.1996$ 